\title{
Heavy Metal Concentrations in Pores and Surface Waters during the Emptying of a Small Reservoir
}

\author{
Christian Opp ${ }^{1}$, Jens Hahn², Nina Zitzer ${ }^{3}$, Gabriela Laufenberg ${ }^{3}$ \\ ${ }^{1}$ Department of Hydrology and Soil Science, Faculty of Geography, University of Marburg, Marburg, Germany \\ ${ }^{2}$ Department of Geography, Faculty of Mathematic and Natural Science, University of Koblenz-Landau, Koblenz, \\ Germany \\ ${ }^{3}$ Mass Spectrometry, Faculty of Pharmacy, University of Marburg, Marburg, Germany \\ Email: opp@staff.uni-marburg.de,jenshahn@uni-koblenz.de
}

Received November 2015

\begin{abstract}
The impact of reservoir emptying on the concentrations of dissolved heavy metals $\mathrm{As}, \mathrm{Cd}, \mathrm{Cr}, \mathrm{Cu}$, $\mathrm{Fe}, \mathrm{Mn}, \mathrm{Ni}, \mathrm{Pb}$ and $\mathrm{Zn}$ ) in pore and surface waters was studied in the Aar Reservoir, a small reservoir in central Germany, during and after the emptying process. This study was conducted to observe binding changes within pore waters as well as the input of dissolved heavy metals in waters of the Aar Creek, what becomes possible when the reservoirs water table is removed and lake sediments become exposed. In pore waters, no clear shifting tendencies between dissolved and sorbed heavy metal fractions could be found after the completed sediment exposure. These relatively low dynamics in pore waters can be explained by the fine texture of the lake sediments, which are characterized by a high water holding capacity, what led to high remaining water contents and therefore slowed down the redox changes. A few days after the completed emptying, a general increase of dissolved heavy metal concentrations occurred in running waters of the Aar Creek as a result of pore water drainage. Here, element specific differences in mobilization and transportation abilities were found, what can be reconstructed by the ratio of dissolved heavy metals in pore and surface waters.
\end{abstract}

\section{Keywords}

Heavy Metals, Reservoirs, Sediments, Surface Waters

\section{Introduction}

Heavy metals with a mass density of $>5 \mathrm{~g} / \mathrm{cm}^{3}$ are natural components in rocks, soils and sediments. In most of the cases they occur in relatively low concentrations, why they are also called trace metals [1]. In consequence of human activities (e.g. mining, industrial emissions, car emissions), heavy metals can be distributed or emitted into the environment. When they hereafter entered into sediments and soils, they can be accumulated and increased in their concentrations, because they are non-degradable. Fluvial sediments often contain increased 
amounts of heavy metals when loaded substrates are entered from the catchment area into the river [2]. Especially the fine-grained sediment fractions and organic components of river and reservoir sediments are able to sorb heavy metals [3] [4].

Since water reservoirs are subject to a continuous sediment input and due to low flow rates at its base mainly fine particles are deposited, large amounts fluvial registered heavy metals can accumulate here [5]. However, the high sorption capacity of fine and organic rich sediments takes place under sufficiently reducing conditions by which the formation of sulfidic compounds counteracts a release of several heavy metals into the pore waters. Dissolved heavy metal contents are also heavily diluted in areas of the water column by the surrounding water body. In addition to the element and substrate specific circumstances especially the prevailing redox conditions determine the binding behavior of heavy metals in sediments [6]. When redox changes occur, particularly before and during the early stabilization of a redox status, an increased release of heavy metals in the dissolved phase becomes possible [7].

The emptying of water reservoirs enhances the oxygen contact of previously water covered sediments. As a result, redox changes inside the pore waters become possible. Simultaneously the hydrostatic uplift is reduced in consequence of the elimination of the water column. This favors a contraction of the exposed lake sediments and the outflow of pore waters, from topographically higher to lower lying areas of the reservoir bottom. Problematic consequences of the targeted emptying of reservoirs are therefore often share shifts between dissolved and fixed heavy metal amounts within the sediments and an enhanced release of elements such as Fe, Mn, $\mathrm{N}$ or $\mathrm{P}$ in the flowing surface water [8]-[14]. In general, sorption dynamics and heavy metal migration during the emptying of reservoirs were observed very seldom.

Since the Aar Reservoir is characterized by a rural catchment area without mining activities, it should have gotten no excessive heavy metal input in its past. Thus, in the reservoirs sediments rather low to moderate heavy metal contents can be expected. However, during the drainage of large pore water amounts an increasing input of dissolved heavy metals to the receiving running water can be expected, resulting of a reduced dilution by surface waters. The different binding properties of elements might hereby affect their mobilization and transport. To address these issues, dissolved concentrations of $\mathrm{As}, \mathrm{Cd}, \mathrm{Cr}, \mathrm{Cu}, \mathrm{Fe}, \mathrm{Mn}, \mathrm{Ni}, \mathrm{Pb}$ and $\mathrm{Zn}$ in lake sediments, pore waters and surface waters of the Aar Creek were analyzed during and after the emptying process.

\section{Study Area}

The Aar Reservoir is situated on the eastern edge of the Rhenish Slate Mountains in the upper reaches of the Aar River. It consists of the main reservoir and a pre-reservoir. With an operating space of approximately 4.1 million $\mathrm{m}^{3}$ and a maximum water depth of $8 \mathrm{~m}$ it is a relatively small and shallow reservoir. Due to predominantly upcoming shales and greywackes relatively moderate geogenetic heavy metal contents in the soils of the catchment and in the reservoirs sediments can be expected, what was confirmed by former investigations [15].

\section{Methods}

An evacuation and emptying of the main basin was carried out from August 2011 for repairing purposes. The sampling of surface waters began on $19^{\text {th }}$ August 2011, even during the emptying process of the reservoir. Pore water sampling started on $30^{\text {th }}$ August 2011, after the bottom of the reservoir had become accessible.

\subsection{Sampling}

1) Surface water

Water samples were taken by means of PE-syringes at three sampling sites within the reservoir and downstream the dam from a depth of about $10 \mathrm{~cm}$. The freshly collected samples were filtered by syringe filters (Minisart NML, Celluloseacetat-Membran, Fa. Sartorius/Göttingen/Germany) in the field at 0.45 microns, acidified in the ratio 100:1 with nitric acid $\left(\mathrm{HNO}_{3}\right)$ and stored in PE-bottles at $-18^{\circ} \mathrm{C}$ up to their analysis.

2) Pore water

Pore waters were obtained by stationary suction pipettes (Macro Rhizon, Fa. Rizosphere Research Products, Wageningen/The Netherlands), that were installed at three locations of the reservoirs bottom, each in $5-10 \mathrm{~cm}$ and 15 - $25 \mathrm{~cm}$ depth. The used pipettes consisted of non absorbent plastic and a microfiltration membrane, whereby the incoming water has been filtered with a pore size of 0.15 - 0.2 microns during its removal. In order 
to ensure the representativeness of the samples, the sampling was carried out from each depth level with a minimum of 3 parallel pipettes. The freshly collected samples were combined to a composite sample and separated in two PE bottles. One half of the origin sample was used for field measurements, the second half was acidified in the ratio 100:1 with nitric acid $\left(\mathrm{HNO}_{3}\right)$ and frozen at $-18^{\circ} \mathrm{C}$ until the determination of heavy metal contents.

3) Substrate

After completion of the pore water extraction, the sample sites were excavated and surveyed. For the determination of the sediments heavy metal contents substrate samples were taken. All samples were air-dried and homogenized in a porcelain mortar. This was followed by a sieving to $<2 \mathrm{~mm}$.

\subsection{Field Measurements}

At each sampling site $\mathrm{pH}$ value and redox potential were determined in the field, immediately after the extraction of pore waters, by means a portable field meter (Multiline P4; Fa. WTW) and adequate electrodes. In parallel, the volumetric soil moisture (HH2, Fa. Delta-T Devices) was recorded in $10 \mathrm{~cm}$ depth of the sediments.

\subsection{Laboratory Analysis}

The proportion of organic matter in the sediments was calculated by determining the loss on ignition for 2 hours at $550^{\circ} \mathrm{C}$. The determination of the particle size distribution was performed by wet sieving and pipette analysis. Heavy metal contents of the sediments were determined by aqua regia extraction. The measurement of element concentrations, in aqua regia extracts as well as in water samples, was carried out by ICP-MS (Fa. Thermo Fisher, X-Series 2).

\section{Results}

The lake sediments were marked by high volumetric water contents and low densities at the beginning of the field campaign. A vegetation cover was absent during the whole sampling period, with the starting evolvement of vascular plants the sampling campaign ended.

Compared within the sampling locations 1 - 3, the sediments textures were relatively homogeneous and contained high silt (45.8 - 65.8 mass \%), moderate clay (22.5 - 33.8 mass \%) and varying sand (6.0 - 31.3 mass \%) contents. The mass of organic matter varied between $4.8 \%$ and $8.6 \%$ and showed decreasing contents with increasing sampling depths. Volumetric soil moisture started with high contents in all sampling locations (77 - 84 vol. \%). As an effect of the sediments high water holding capacity, only slight decreases of moisture occurred with enduring sediment exposure, which reached at the end of the sampling campaign $12.8-22.4$ vol. \% of the maximum contents (Figure 1). The pore waters $\mathrm{pH}$ varied over all sampling locations from $\mathrm{pH} 6.6$ to $\mathrm{pH} 7.6$, while each location and sampling depth showed only very slight $\mathrm{pH}$ variations. A similar behavior was found for the redox potential, which locally underlay only small variations with a range of $64 \mathrm{mV}$ to $135 \mathrm{mV}$ in all sampled pore waters. These more or less constant redox states within the whole sampling campaign are a result of high remaining water contents inside the exposed sediments, what hindered an enhanced oxygen exchange between sediments and atmosphere, and therefore an establishment of more oxic conditions.
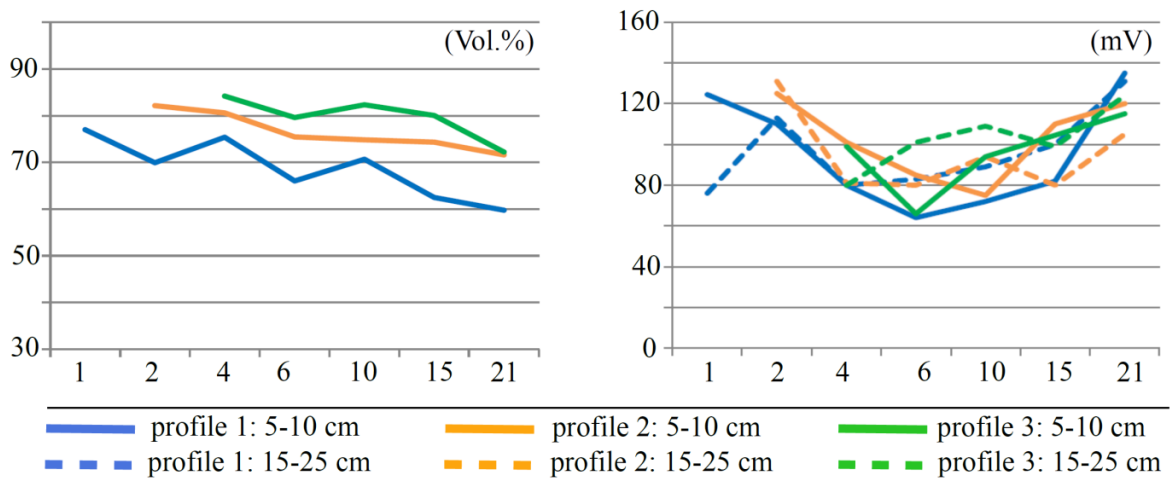

Figure 1. Temporal variations (x-axis: number of days after the complete sediment exposure) of volumetric water content and redox potential (y-axis) in pore waters of sampling profiles 1 - 3 . 


\subsection{Heavy Metal Concentrations in Sediments and Pore Waters}

Heavy metal concentrations in the sediments showed no dramatic differences between different sampling locations and sampling depths (Table 1). In all, the ranges of As (4.7 - $7.0 \mathrm{mg} / \mathrm{kg}), \mathrm{Cd}(0.2-0.3 \mathrm{mg} / \mathrm{kg}), \mathrm{Cr}(23.4$ $39.6 \mathrm{mg} / \mathrm{kg})$, Cu (13.6 - $21.5 \mathrm{mg} / \mathrm{kg})$, Fe (26.7 - $39.2 \mathrm{~g} / \mathrm{kg})$, Mn (0.66 - $1.3 \mathrm{~g} / \mathrm{kg})$, Ni (23.8 - $37.9 \mathrm{mg} / \mathrm{kg}), \mathrm{Pb}$ $(15.8-23.3 \mathrm{mg} / \mathrm{kg}$ ) and $\mathrm{Zn}(57.6$ - $82.0 \mathrm{mg} / \mathrm{kg})$ attained low to moderate concentrations, compared to the geogenic background values for claystone and greywackes [16].

Dissolved concentrations in the pore waters were also low to moderate (Table 2), with ranges of As (3.1 -

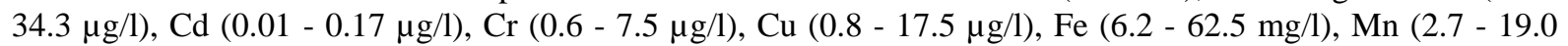
$\mathrm{mg} / \mathrm{l})$, Ni (0.7 - $7.3 \mu \mathrm{g} / \mathrm{l}), \mathrm{Pb}(0.2-3.1 \mu \mathrm{g} / \mathrm{l})$ and Zn (11.3 - $256 \mu \mathrm{g} / \mathrm{l})$. Stronger differences of dissolved metal contents were present within different sampling locations, but no relations of concentration changes and ongoing sediment exposure could be observed. The presence of in all small temporal variations can be seen as a result of a more or less constant redox state with continuous reducing conditions inside the sediments, which is also proven by high remaining concentrations of dissolved Fe and $\mathrm{Mn}$ in all sampling depths and locations. Changes in sorption processes and metal mobility should hereby occur only after a longer time of sediment exposure and a stronger decrease of the sediments water content.

\subsection{Heavy Metals in Surface Waters}

The observation of surface waters of the Aar Creek started at $19^{\text {th }}$ August 2011 downstream the dam (site A) during the emptying process. After the reservoir basin was accessible, additional sampling of creek water started from $30^{\text {th }}$ August 2011 in the reservoirs middle (site B) and root (site C). In waters of the Aar Creek, dissolved heavy metals showed strong variations with ongoing time of sediment exposure. Whereas during the process of reservoir emptying very low concentrations occurred in general, rising concentrations with factors of 10 to 30 could be measured few days after it was completed. This was observed at all sampling locations for all elements, with the exception of dissolved As. The highest concentration peaks were measured at site A, downstream the reservoirs dam (Figure 2). A tendency of decreasing concentrations within this export of dissolved metals was found 46 days after completed sediment exposure at the last sampling day $\left(14^{\text {th }}\right.$ October 2011$)$. This is assumed as an effect of a reduced pore water drainage.
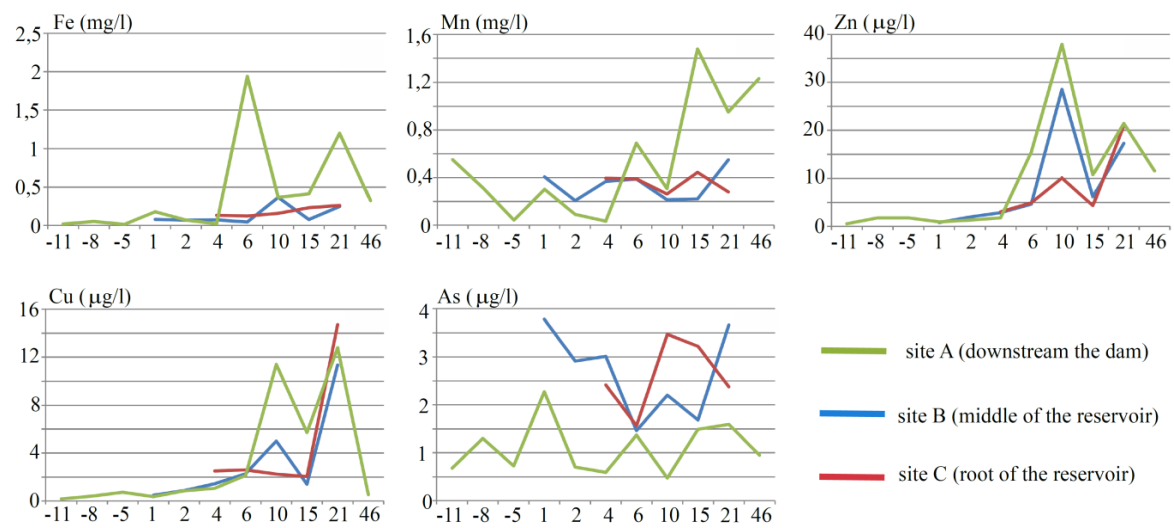

Figure 2. Temporal variations of dissolved Fe, Mn, Zn, Cu and As concentrations in the Aar Creek (number of days before the total exposure of the sediments in negative values, number days after the completed exposure in positive values).

Table 1. Heavy metal concentrations in lake sediments (aqua regia extraction) at the sampling sites profile 1 - 3.

\begin{tabular}{ccccccccccc}
\hline Profile & $\begin{array}{c}\text { Depth } \\
(\mathrm{cm})\end{array}$ & $\begin{array}{c}\mathrm{As} \\
(\mathrm{mg} / \mathrm{kg})\end{array}$ & $\begin{array}{c}\mathrm{Cd} \\
(\mathrm{mg} / \mathrm{kg})\end{array}$ & $\begin{array}{c}\mathrm{Cr} \\
(\mathrm{mg} / \mathrm{kg})\end{array}$ & $\begin{array}{c}\mathrm{Cu} \\
(\mathrm{mg} / \mathrm{kg})\end{array}$ & $\begin{array}{c}\mathrm{Fe} \\
(\mathrm{g} / \mathrm{kg})\end{array}$ & $\begin{array}{c}\mathrm{Mn} \\
(\mathrm{g} / \mathrm{kg})\end{array}$ & $\begin{array}{c}\mathrm{Ni} \\
(\mathrm{mg} / \mathrm{kg})\end{array}$ & $\begin{array}{c}\mathrm{Pb} \\
(\mathrm{mg} / \mathrm{kg})\end{array}$ & $\begin{array}{c}\mathrm{Zn} \\
(\mathrm{mg} / \mathrm{kg})\end{array}$ \\
\hline \multirow{2}{*}{1} & $0-5 \mathrm{~cm}$ & 4.7 & 0.20 & 23.4 & 13.6 & 26.7 & 0.85 & 23.8 & 16.0 & 57.6 \\
& $6-10 \mathrm{~cm}$ & 4.8 & 0.19 & 25.2 & 14.6 & 27.9 & 0.66 & 25.3 & 15.8 & 59.1 \\
2 & $0-5 \mathrm{~cm}$ & 6.1 & 0.31 & 35.7 & 21.5 & 38.2 & 1.31 & 37.9 & 20.0 & 80.4 \\
& $6-10 \mathrm{~cm}$ & 7.0 & 0.30 & 39.6 & 21.5 & 39.2 & 0.90 & 21.5 & 22.6 & 82.0 \\
3 & $0-5 \mathrm{~cm}$ & 4.8 & 0.27 & 28.9 & 18.6 & 31.8 & 1.05 & 29.8 & 20.2 & 68.8 \\
& $6-10 \mathrm{~cm}$ & 5.4 & 0.27 & 27.0 & 16.7 & 26.9 & 0,76 & 27.1 & 23.3 & 61.2 \\
\hline
\end{tabular}


Table 2. Median values of dissolved heavy metal concentrations in pore waters in $5-10 \mathrm{~cm}$ and $15-25 \mathrm{~cm}$ depth of each sampling profile ( $\mathrm{n}=6$ for each depth).

\begin{tabular}{|c|c|c|c|c|c|c|c|c|c|c|}
\hline Profile & $\begin{array}{l}\text { Depth } \\
(\mathrm{cm})\end{array}$ & $\begin{array}{c}\text { As } \\
(\mu \mathrm{g} / \mathrm{l})\end{array}$ & $\begin{array}{c}\mathrm{Cd} \\
(\mu \mathrm{g} / \mathrm{l})\end{array}$ & $\begin{array}{c}\mathrm{Cr} \\
(\mu \mathrm{g} / \mathrm{l})\end{array}$ & $\begin{array}{c}\mathrm{Cu} \\
(\mu \mathrm{g} / \mathrm{l})\end{array}$ & $\begin{array}{c}\mathrm{Fe} \\
(\mathrm{mg} / \mathrm{l})\end{array}$ & $\begin{array}{c}\mathrm{Mn} \\
(\mathrm{mg} / \mathrm{l})\end{array}$ & $\begin{array}{c}\mathrm{Ni} \\
(\mu \mathrm{g} / \mathrm{l})\end{array}$ & $\begin{array}{c}\mathrm{Pb} \\
(\mu \mathrm{g} / \mathrm{l})\end{array}$ & $\begin{array}{c}\mathrm{Zn} \\
(\mu \mathrm{g} / \mathrm{l})\end{array}$ \\
\hline \multirow[t]{2}{*}{1} & $5-10 \mathrm{~cm}$ & 29.5 & 0.02 & 1.6 & 1.9 & 15.3 & 6.6 & 1.9 & 0.58 & 49.1 \\
\hline & $15-25 \mathrm{~cm}$ & 28.6 & 0.02 & 1.2 & 7.1 & 32.8 & 5.3 & 1.6 & 0.70 & 56.8 \\
\hline \multirow[t]{2}{*}{2} & $5-10 \mathrm{~cm}$ & 24.3 & 0.01 & 1.5 & 2.0 & 18.1 & 6.8 & 1.8 & 0.48 & 96.8 \\
\hline & $15-25 \mathrm{~cm}$ & 28.1 & 0.02 & 1.6 & 4.2 & 40.7 & 6.0 & 2.1 & 0.91 & 64.9 \\
\hline \multirow[t]{2}{*}{3} & $5-10 \mathrm{~cm}$ & 7.0 & 0.03 & 1.07 & 4.25 & 12.9 & 6.11 & 2.21 & 1.18 & 31.1 \\
\hline & $15-25 \mathrm{~cm}$ & 19.3 & 0.02 & 2.97 & 3.96 & 33.1 & 10.9 & 2.1 & 1.08 & 85.3 \\
\hline
\end{tabular}

In all, the range of metal concentrations in waters of the Aar Creek was for As (0.48 - $3.78 \mu \mathrm{g} / \mathrm{l})$, Cd (0.003 $0.076 \mu \mathrm{g} / \mathrm{l})$, Cr $(0.11$ - $2.32 \mu \mathrm{g} / \mathrm{l})$, Cu (0.36 - $14.7 \mu \mathrm{g} / \mathrm{l}), \mathrm{Fe}(0.02$ - $1.94 \mathrm{mg} / \mathrm{l}), \mathrm{Mn}(0.03$ - $1.48 \mathrm{mg} / \mathrm{l}), \mathrm{Ni}(0.22$ $5.41 \mu \mathrm{g} / \mathrm{l}), \mathrm{Pb}(0.072$ - $2.95 \mu \mathrm{g} / \mathrm{l})$ and $\mathrm{Zn}(0.81$ - $38.0 \mu \mathrm{g} / \mathrm{l})$. The concentration peaks reached at the one hand in all moderate concentrations, which did not exceed water statutory threshold values. At the other hand, these concentrations occurred some days after complete sediment exposure temporarily in a similar concentration scale as in the pore waters. Although the sediments contained low to moderate heavy metal concentrations, the reservoirs emptying led by the drainage of pore waters to a strong increase of the Aar Creeks heavy metal load.

\section{Discussion}

As a result of reservoir emptying, strong changes in the heavy metal load of the former dammed Aar Creek were observed, whereas pore waters remained more or less constant in their concentrations, $\mathrm{pH}$-values and redox potentials. These relatively low dynamics in pore waters are an effect of the sediments high water holding capacity, high remaining water contents and therefore slowed down redox changes. With ongoing exposure and ongoing drying of the sediments, rising concentration of dissolved $\mathrm{Cd}, \mathrm{Mn}$ and $\mathrm{Zn}$ in the pore waters have to be assumed, resulting from an establishment of more oxic conditions [17] [18]. But, also the amount of pore water drainage and exported dissolved heavy metals should decrease simultaneously to this. Hence, oxidation processes inside the lake sediments should play only a minor role on the export of dissolved heavy metals in downstream situated river zones after the emptying of reservoirs.

As the oxygen supply to dissolved elements rises during and after pore water drainage, the ability of some elements to aquatic transport might be modified. The significance of these processes within metal deposition can be supposed by the comparison of the heavy metal concentrations in creek and pore waters.

As the scale of in running waters occurring concentration rises after sediment exposure is depending on the creeks metal concentrations before emptying, the precision of in Table $\mathbf{3}$ presented percentages could be partly limited. Nevertheless, clear differences in the transportability of some elements are visible. Especially the export of dissolved Fe decreases during the drainage of pore waters in the Aar Creek: Although dissolved Fe concentrations rise within the running waters, only $1 \%$ of its pore water concentrations are achieved here. As it showed the comparatively highest concentration discrepancy between waters of the Aar Creek and pore waters, a much higher concentration rise should occur, if dissolved Fe was not removed from the water table after pore water drainage. In surface waters, dissolved Mn achieves only 6\% of the mean pore water concentrations. As both elements achieve only a low solubility under oxic conditions and the present $\mathrm{pH}$ values [19], which are involved in the formation of hydroxides, they are either transferred to the creeks particulate heavy metal fraction or removed from the water column by the formation of precipitates. The same happens to dissolved As, which is under $\mathrm{pH} 4$ - 9 mainly present as negatively charged, highly to Fe-(hydr-)oxides sorbable arsenate $\mathrm{H}_{2} \mathrm{AsO}_{4}^{-}$or $\mathrm{HAsO}_{4}^{2-} \quad$ [20]. With the inset of oxic conditions during and after pore water drainage, it should be quickly depleted of its dissolved state.

In opposite, dissolved $\mathrm{Cd}, \mathrm{Cr}, \mathrm{Cu}, \mathrm{Ni}$ and $\mathrm{Pb}$ underlay only small concentration losses during and after pore water drainage. The relative low differences between concentrations in pore- and surface waters prove a comparably low retention of these elements, in accordance to investigations in brackish sediments [21]. Only dissolved $\mathrm{Zn}$, with $19.3 \%$ of the pore water concentrations inside the surface waters, indicates a slightly better retention.

The response of downstream situated aquatic biota to rising concentrations of dissolved heavy metals is hard to assess. This is due to the interaction of several factors as a metals binding state, species and age of a downstream situated organism [22], pH-value [23] or the endurance of an occurring concentration peak, that at least 
Table 3. Median values of dissolved heavy metals in pore-( $\mathrm{Pw})$ and surface waters $(\mathrm{Sw})$ and their percental ratio $(\mathrm{Sw} *$ $[100 / \mathrm{Pw}])$.

\begin{tabular}{|c|c|c|c|c|c|c|c|c|c|c|}
\hline Sample & $\mathrm{n}$ & $\begin{array}{c}\text { As } \\
(\mu \mathrm{g} / \mathrm{l})\end{array}$ & $\begin{array}{c}\mathrm{Cd} \\
(\mu \mathrm{g} / \mathrm{l})\end{array}$ & $\begin{array}{c}\mathrm{Cr} \\
(\mu \mathrm{g} / \mathrm{l})\end{array}$ & $\begin{array}{c}\mathrm{Cu} \\
(\mu \mathrm{g} / \mathrm{l})\end{array}$ & $\begin{array}{c}\mathrm{Fe} \\
(\mathrm{mg} / \mathrm{l})\end{array}$ & $\begin{array}{c}\mathrm{Mn} \\
(\mathrm{mg} / \mathrm{l})\end{array}$ & $\begin{array}{c}\mathrm{Ni} \\
(\mu \mathrm{g} / \mathrm{l})\end{array}$ & $\begin{array}{c}\mathrm{Pb} \\
(\mu \mathrm{g} / \mathrm{l})\end{array}$ & $\begin{array}{c}\mathrm{Zn} \\
(\mu \mathrm{g} / \mathrm{l})\end{array}$ \\
\hline $\mathrm{Sw}^{1}$ & 13 & 1.57 & 0.01 & 0.8 & 2.25 & 0.23 & 0.39 & 1.28 & 0.50 & 10.1 \\
\hline $\mathrm{Pw}^{2}$ & 36 & 24.1 & 0.02 & 1.55 & 3.72 & 22.3 & 6.38 & 1.9 & 0.73 & 52.3 \\
\hline \multicolumn{2}{|c|}{$\mathrm{Sw} *(100 / \mathrm{Pw})(\%)$} & 6.5 & 50.0 & 51.6 & 60.5 & 1.0 & 6.1 & 67.4 & 68.5 & 19.3 \\
\hline
\end{tabular}

${ }^{1}$ = Surface waters, median values refer only to sampling data that were generated after the sediment exposure was completed (between day 1 to 46 after sediment exposure); ${ }^{2}=$ pore waters (median values include all sampling data).

determine the toxicity. The negative impact of enhanced dissolved heavy metal concentration is again relativized by the fact, that it is only one stressor to aquatic biota simultaneous to an intensified export of sediments [24], enhanced concentrations of suspended matter [25], rising concentration of the particulate heavy metal fraction or stronger variations of the creeks discharge.

However, the occurrence of an obvious heavy metal export to the Aar Creek in the absence of metal pollutions inside the lakes sediments, leads to the suggestion that a much higher heavy metal input in running waters might occur in the presence of polluted sediments or under more acidic conditions. This should be the case especially for sediments with high concentrations of $\mathrm{Cd}, \mathrm{Cr}, \mathrm{Cu}, \mathrm{Ni}$ and $\mathrm{Pb}$. In consideration to this, the export of dissolved heavy metals and nutrients should always be taken into account during the complete emptying of reservoirs. As some metals seem to be transportable within running waters along distances of several kilometers, they represent a potential risk to downstream situated biological communities or fish farms, when the drainage of pore waters to surface waters occurs.

\section{References}

[1] Alloway, B.J., Ed. (1990) Heavy Metals in Soils. Wiley, New York.

[2] Schulz-Zunkel, C. and Krüger, F. (2009) Trace Metal Dynamics in Floodplain Soils of the River Elbe: A Review. Journal of Environmental Quality, 38, 1349-1362. http://dx.doi.org/10.2134/jeq2008.0299

[3] Fenninger, A., Stattegger, K., Manser, P., Plass, N. and Scholger, R. (1988) Sedimentgeologische Untersuchungen an Stauraumsedimenten der Mur: Eine Vorstudie am Beispiel der Staustufe Mellach. Mitteilungen des Naturwissenschaftlichen Vereins für Steiermark, 118, 107-118.

[4] Westrich, B., Kern, U. and Haag, I. (2000) Mobilität von Schadstoffen in den Sedimenten staugeregelter FlüsseDynamik und Bilanzierung von Schwebstoffen und Schwermetallen in einer Stauhaltungskette.

http://www.fachdokumente.lubw.baden-wuerttemberg.de/servlet/is/5121/

[5] Ulrich, K.U., Paul, L. and Hupfer, M. (2000) Schadstoffgehalte in den Sedimenten von Staugewässern. Wasser und Boden, 52/10, 27-32.

[6] Guo, T., De Laune, R.D. and Patrick, W.H. (1997) The Influence of Sediment Redox Chemistry on Chemically Active Forms of Arsenic, Cadmium, Chromium and Zink in Estuarine Sediment. Environment International, 23/3, 305-316. http://dx.doi.org/10.1016/S0160-4120(97)00033-0

[7] Van den Berg, G.A., Loch, J.P. and Winkels, H.J. (1998) Effect of Fluctuating Hydrological Conditions on the Mobility of Heavy Metals in Soils of a Freshwater Estuary in the Netherlands. Water, Air and Soil Pollution, 102, 377-388. http://dx.doi.org/10.1023/A:1004920700598

[8] Ahearn, D.S. and Dahlgren, R.A. (2005) Sediment and Nutrient Dynamics Following a Low-Head Dam Removal at Murphy Creek, California. Limnology and Oceanography, 50, 1752-1762. http://dx.doi.org/10.4319/lo.2005.50.6.1752

[9] Bushaw-Newton, K., Hart, D., Pizzuto, J., Thomson, J., Egan, J., Ashley, J., Johnson, D., Horwitz, R., Keeley, M., Lawrence, J., Charles, D., Gatenby, C., Kreeger, D., Nightengale, T., Thomas, R. and Velinsky, D. (2002) An Integrative Approach towards Understanding Ecological Responses to Dam Removal: The Manatawny Creec Study. Journal of the American Water Resources Association, 38, 1581-1599. http://dx.doi.org/10.1111/j.1752-1688.2002.tb04366.x

[10] Dagnac, J. (1994) Bilan des depots sedimentaires dans la reservoir de Pareloup (Aveyron, France). Hydroecologie Applique, 6, 59-85. http://dx.doi.org/10.1051/hydro:1994004

[11] Merle, G., Mosnier, D. and Tourenq, J.N. (1994) La vindange de la retenue de Pareloup en 1993: Une etape-clef dans la vie du lac. Hydroecologie Applique, 6, 427-446. http://dx.doi.org/10.1051/hydro:1994018

[12] Orr, C.H., Rogers, K.L. and Stanley, E.H. (2006) Channel Morphology and P Uptake Following Removal of a Small 
Dam. Journal of the North American Benthological Society, 25, 556-568. http://dx.doi.org/10.1899/0887-3593(2006)25[556:CMAPUF]2.0.CO;2

[13] Stanley, E.H. and Doyle, M.W. (2002) A Geomorphic Perspective on Nutrient Retention Following Dam Removal. Bioscience, 52, 693-701. http://dx.doi.org/10.1641/0006-3568(2002)052[0693:AGPONR]2.0.CO;2

[14] Ulrich, K.U. (1998) Vergleichende Untersuchungen zu Auswirkungen des Sediments auf die Wasserbeschaffenheit in Trinkwassertalsperren unter Berücksichtigung von Stauspiegelschwankungen. Cuvillier, Göttingen.

[15] Hampel, U. (2013) Schwermetallkonzentrationen in Bach- und Ufersedimenten im Einzugsgebiet der Aartalsperre. Diploma Thesis, Philipps-University of Marburg, Marburg.

[16] LABO (Bund- und Länderarbeitsgemeinschaft Bodenschutz) (2003) Hintergrundwerte für anorganische und organische Stoffe in Böden. 3rd Edition. http//:www.labo-deutschland.de/documents/LABO-HGW-Text 4e3.pdf

[17] Gambrell, R.P., Wiesepape, J.B., Patrick, W.H. and Duff, M.C. (1991) The Effects of pH, Redox, and Salinity on Metal Release from a Contaminated Sediment. Water, Air and Soil Pollution, 57-58, 359-367. http://dx.doi.org/10.1007/BF00282899

[18] Saeki, K., Okazaki, M. and Matsumoto, S. (1993) The Chemical Phase Changes of Heavy Metals with Drying and Oxidation of the Lake Sediments. Water Research, 27/7, 1243-1251. http://dx.doi.org/10.1016/0043-1354(93)90017-C

[19] Alloway, B.J. and Ayres, D.C. (1996) Schadstoffe in der Umwelt. Spektrum, Heidelberg.

[20] Cheng, H., Hu, Y., Luo, J., Xu, B. and Zhao, J. (2009) Geochemical Processes Controlling Fate and Transport of Arsenic in Acid Mine Drainage (AMD) and Natural Systems. Journal of Hazardous Materials, 165, 13-26. http://dx.doi.org/10.1016/j.jhazmat.2008.10.070

[21] Förstner, U., Calmano, W. and Ahlf, G. (1999) Sedimente als Schadstoffsenken und -quellen: Gedächtnis, Schutzgut, Zeitbombe, Endlager. In: Frimmel, F., Ed., Wasser und Gewässer: Ein Handbuch. Spektrum, Heidelberg.

[22] LAWA (Länderarbeitsgemeinschaft Wasser) (1998) Zielvorgaben zum Schutz oberirdischer Binnengewässer, Band II. Kulturbuchverlag, Berlin.

[23] UBA (Umweltbundesamt) (2001) Sachstandsbericht: Abtrag von Kupfer und Zink von Dächern, Dachrinnen und Fallrohren durch Niederschläge. https://www.umweltbundesamt.de/publikationen/abtrag-von-kupfer-zink-von-daechern-dachrinnen

[24] Stanley, E.H. and Doyle, M.W. (2003) Trading off: The Ecological Effects of Dam Removal. Frontiers in Ecology and the Environment, 1, 15-22. http://dx.doi.org/10.1890/1540-9295(2003)001[0015:TOTEEO]2.0.CO;2

[25] Gray L.J. and Ward, J.V. (1982) Effects of Sediment Releases from a Reservoir on Stream Macroinvertebrates. Hydrobiologia, 96, 177-184. http://dx.doi.org/10.1007/BF02185433 